\title{
STUDI INTERPRETIF UNTUK MEMAHAMI PERILAKU KEENGGANAN MENGGUNAKAN E-BILLING
}

\author{
Elana Era Yusdita \\ Pendidikan Akuntansi FKIP \\ Universitas PGRI Madiun \\ elaradita@gmail.com
}

\begin{abstract}
ABSTRAK
Penelitian ini bertujuan untuk mengetahui penyebab wajib pajak enggan menggunakan e-billing. Penelusuran penyebab tersebut dilakukan dengan paradigma interpretif dengan metode fenomenologi transendental. Informan dalam riset ini adalah pengusaha UMKM yang memiliki kewajiban membayar pajak menggunakan e-billing, namun mewakilkannya kepada orang lain. Hasil penelitian menunjukkan kesadaran terdalam informan pertama adalah anggapan wajar akan ketidakmampuan sistem terelektronisasi memicu keengganan belajar teknologi baru, seperti $e$-billing. Menurut informan kedua, pengalaman mengurus pajak yang berbelit-belit secara manual dan pengalaman masa lalu membuat informan tidak mau mempelajari cara menggunakan $e$ billing. Pemerintah dapat mempertimbangkan sistem pembayaran manual untuk melayani wajib pajak yang tidak menguasai $e-$ billing.
\end{abstract}

Kata Kunci: E-billing; Perilaku wajib pajak; Sistem pajak; Fenomenologi transendental

\section{ABSTRACT}

This study aims to determine the causes of taxpayers reluctant to use ebilling. The cause search is done by interpretive paradigm with transcendental phenomenology method. Informants of this reseach are UMKM entrepreneurs who have the obligation to pay taxes using ebilling, but representing it to others. The results show that the inner awareness of the first informant is a reasonable assumption of the inability of the electronized system to trigger a reluctance to learn new technologies, such as e-billing. According to the second informant, the experience of manually managing taxes and past experiences made informants unwilling to learn how to use e-billing. The government may consider a manual payment system to serve taxpayers who do not possess e-billing.

Keywords: E-billing; Taxpayer behavior; Tax system; Transcendental phenomenology

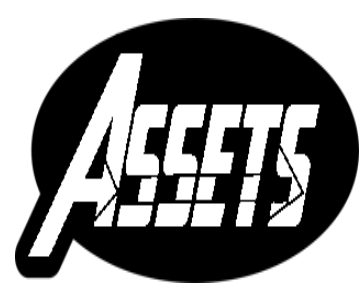

ASSETS:

Jurnal Akuntansi dan Pendidikan Vol. 6 No. 1

Hlmn. 85-92

Madiun, April 2017 p-ISSN: 2302-6251

e-ISSN: 2477-4995

Artikel masuk:

1 Maret 2017

Tanggal diterima:

31 Maret 2017 


\section{ASSEES JURNAL AKUNTANSI DAN PENDIDIKAN

\section{PENDAHULUAN}

Berdasarkan self assessment system yang dianut oleh Indonesia, wajib pajak memiliki kewajiban menghitung, membayar, dan melaporkan pajaknya sendiri. Direktorat Jenderal Pajak (DJP) mengharapkan wajib pajak melaporkan jumlah pajak terutang yang sebenar-benarnya karena telah diberi kebebasan untuk menghitung sendiri. Wajib pajak dianggap mandiri karena ialah yang paling mengerti atas kegiatan ekonomi yang ia lakukan.

Penerapan self assessment system membutuhkan kepatuhan pajak sukarela (Saad, 2014). Kepatuhan pajak sukarela ini juga meliputi keharusan untuk memahami undang-undang perpajakan, menghitung dan membayar jumlah pajak yang tepat sesuai peraturan yang berlaku, termasuk melakukan pencatatan yang benar (Sapiei dan Kasipillai, 2013). Sanggup maupun tidak, segala ketetapan DJP termasuk penerapan sistem perpajakan harus diikuti oleh wajib pajak. Direktorat Jenderal Pajak (DJP) sebagai divisi khusus di Kementrian Keuangan yang mengurus administrasi pajak di Indonesia mengubah sistem pembayaran pajak di Indonesia manual menjadi e-billing pada 1 Januari 2016 berdasarkan Surat Edaran Direktorat Jenderal Pajak Nomor SE-11/PJ/2016.

E-billing sebagai sistem pembayaran pajak terelektronisasi memerlukan beberapa langkah. Pertama, wajib pajak membuat kode billing. DJP menyediakan berbagai cara untuk membuat kode billing, yaitu melalui aplikasi DJP online (SSE1, SSE2, SSE3), layanan billing-djp atau di KPP atau KP2KP, Kring Pajak 1500200, melalui teller atau CS bank dan kantor pos, internet banking, penyedia jasa aplikasi eklektronik (ASP), menghubungi SMS ID billing *141*500\#. Kedua, wajib pajak membayar pajak dengan memakai kode billing melalui salah satu pilihan cara pembayaran, yaitu teller bank/kantor pos, mini ATM, internet banking dan mobile banking, serta melalui ATM. Sesuai Surat Direktur Jenderal Pajak no S-355/PJ/2016. DJP kini menyediakan kemudahan bagi pengusaha yang memiliki kewajiban membayar pajak terutang sesuai PP no 46 tahun 2013 tanpa pembuatan kode billing, yaitu melalui ATM BNI dan BCA. DJP telah berupaya menyediakan berbagai alternatif bagi wajib pajak untuk menyelesaikan kewajibannya.

E-billing adalah sistem pembayaran pajak termutakhirkan dengan menggunakan kode billing. Kode billing merupakan kode identifikasi yang diterbitkan melalui sistem billing atas suatu jenis pembayaran atau setoran pajak yang akan dilakukan wajib pajak. Pada awal penerapan sistem pembayaran, wajib pajak membayar langsung ke Kantor Kas Negara (Administratie Kantoor Voor de Landkassen). Saat pembayaran pajak dapat dilakukan melalui bank, muncullah sebutan Bank Persepsi. Cara ini didasarkan pada TUPRP (Tata Usaha Penerimaan dan Restitusi Pajak) pada 1994, namun pembayaran masih bersifat offline. Sistem pembayaran online baru digagas pada saat terjadi perubahan offline kepada online banking system akibat revolusi perbankan, adanya kebangkitan sistem informasi, dan munculnya DotCom. DJP mengeluarkan MP3 (Monitoring Pelaporan dan Pembayaran Pajak). Undang-Undang Keuangan Negara dan Undang Undang Perbendaharaan menggagas Modul Penerimaan Negara (MPN). Bentuk awal dari MPN disebut Modul Penerimaan Negara Generasi Pertama (MPN-G1). MPN-G1 dipakai oleh e-billing Direktorat Jenderal Pajak dan mekanisme pembayaran pajak lainnya yang selama ini digunakan. Pada saat MPN-G2 muncul, ebilling yang menggunakan alamat website sse.pajak.go.id berubah menjadi e-billing DJP online dengan alamat sse2.pajak.go.id.

Sistem MPN G2 ini disusun untuk memperbaiki sistem MPN G1. Modul Penerimaan Negara ini diklaim DJP telah dapat menyatukan sistem penerimaan negara yang terpisah antara sistem perbankan dan sistem penagihan. Sistem 
perbankan merupakan komponen pihak yang menerima pembayaran pajak yaitu bank dan kantor pos, sedangkan sistem penagihan dikelola oleh Direktorat Jenderal Pajak, Direktorat Bea dan Cukai, dan Direktorat Jenderal Anggaran. Sistem yang menghubungkan keduanya ada di dalam tanggung jawab Direktorat Jenderal Perbendaharaan, sedangkan pengelolaan infrastruktur dilakukan oleh Pusat Sistem Infromasi dan Teknologi Keuangan Sekretariat Jenderal. MPN G2 ini diharapkan mendukung pelaksanaan manajemen kas Treasury Single Account yang baik bersifat real time dan handal.

Pergantian transisi implementasi dari MPN G1 menuju MPN G2 membuat sistem pembayaran pajak melalui non-bank BUMN, BUMD, atau Kantor Pos Persepsi bermekanisme e-billing. Meskipun begitu, pembayaran pajak masih dapat menggunakan Surat Setoran Pajak (SSP) hingga tanggal 30 Juni 2016. Mekanisme ebilling secara resmi dan murni diterapkan mulai 1 Juli 2016.

Sistem billing pada e-billing versi pertama dengan kedua juga terdapat perbedaan dengan adanya fitur tambahan pada pembuatan billing atas NPWP pihak lain untuk jenis pajak potongan atau pungutan, serta adanya pembuatan billing untuk jenis pembayaran pajak tanpa NPWP untuk jenis pajak tertentu. Sistem billing itu sendiri merupakan sistem yang menangani penerbitan kode billing untuk pembayaran atau pennyetoran penerimaan negara secara elektronik, sehingga wajib pajak tidak perlu membuat Surat Setoran (SSP, SSBP, SSPB) secara manual. Selain itu, sistem yang baru tidak terbatas pada mata uang tunggal, namun juga bisa melayani valuta asing.

Wajib pajak mengeluh kesulitan pada saat menerapkan e-billing karena susah mengakses website DJP pada sepanjang waktu (Angkasa, 2017). Tanggapan pihak DJP atas keluhan tersebut adalah memberikan saran agar wajib pajak bersangkutan membuat kode billing sebelum batas waktu pembayaran tiba (Budiarto, 2017). Selain itu, DJP menyarankan jalur pembuatan kode billing selain melalui situs DJP online. Hal ini menunjukkan adanya hambatan dalam implementasi e-billing. Peneliti tertarik meneliti persepsi wajib pajak yang enggan menggunakan e-billing, tidak hanya sebab yang tampak seperti kesulitan akses internet atau sebab teknis lainnya, namun menulusuri pengalaman wajib pajak untuk mengupas tuntas penyebabnya.

\section{METODE PENELITIAN}

Penelitian ini menggunakan pendekatan keperilakuan untuk menjawab fenomena dalam perpajakan karena pendekatan ini dipandang dapat memberi pandangan yang lebih luas dalam memahami perilaku individu, yaitu wajib pajak (James dan Alley, 2002). Wajib pajak tidak dipandang sebagai penentu laba dan rugi dalam sistem perpajakan sebuah negara, namun sebagai warga negara yang baik yang memegang prinsip keadilan (James dan Alley, 2002). Pendekatan keperilakuan mengarahkan peneliti untuk melihat aspek terbentuknya perilaku atau tindakan tertentu. Perilaku seseorang dipicu oleh niat, sedangkan niat memiliki determinan, antara lain sikap terhadap sebuah tindakan tertentu, norma subjektif, dan perilaku kontrol persepsian (Ajzen, 1991). Terlepas dari kerangka teori perilaku yang digagas oleh Ajzen (1991), peneliti ingin menelusuri lebih dalam penyebab wajib pajak enggan menggunakan e-billing. Yusdita (2016) menemukan bahwa beberapa responden tidak patuh terhadap peraturan perpajakan karena ketidakmampuan mereka menggunakan sistem perpajakan terelektronisasi dan jauhnya jarak tempat tinggal wajib pajak dengan Kantor Pelayanan Pajak (KPP) sebagai tempat pelaporan pajak serta bank dan/ atau kantor pos sebagai tempat pembayaran pajak. Alasan ini tidak dapat ditemukan dalam jawaban item kuesioner dengan skala likert tujuh poin, jika Yusdita (2016) tidak mendengar penuturan beberapa responden. Peneliti ingin keluar dari struktur teori 


\section{ASSEES JURNAL AKUNTANSI DAN PENDIDIKAN

yang kokoh dan melibatkan wajib pajak sebagai pencipta realitas (Chua, 1986). Alasan ini membuat peneliti ingin mendalami keengganan penggunaan e-billing dengan metode interpretif.

Interpretif merupakan sebuah metode yang meyakini bahwa realitas ada di dalam kesadaran manusia yang terbentuk dari pengalaman pribadi (Kamayanti, 2016: 29). Artinya, keengganan penggunaan e-billing ada karena sesuatu dari pengalaman wajib pajak. Riset ini, dengan menggunakan interpretif, diharapkan dapat membantu dan memaknai alasan di balik suatu aksi sosial (Kamayanti, 2016: 30).

Fokus interpretif adalah informan sebagai individu. Jadi penelitian ini menggunakan informan wajib pajak yang seharusnya menerapkan e-billing, namun tidak melaksanakan. Menurut PMK No 243/PMK.03/2014 tentang Surat Pemberitahuan (SPT) Pasal 18, WPOP yang melakukan pekerjaan bebas tidak dikecualikan dari kewajiban untuk menyampaikan SPT Masa. Artinya, WPOP yang melakukan pekerjaan bebas murni menerapkan self assesment system karena tidak menerima gaji yang telah dipotong Pajak Penghasilan dari pemberi kerja. WPOP dengan karakteristik seperti ini merupakan pengguna wajib e-billing. Peneliti mencari usahawan yang berNPWP, mengetahui tentang eksistensi e-billing, namun tidak menggunakannya. Alternatifnya adalah WPOP usahawan yang mengalihkan tugas pengisian e-billing kepada orang lain. Peneliti berhasil menemukan satu orang yang memiliki karakteristik seperti ini, yaitu seorang pengusaha jasa sewa lapak pasar di dua pasar di Madiun. Pengusaha ini memiliki omset kurang dari 4,8 M setahun, sehingga dikenai kewajiban membayar pajak sesuai PP 46, berupa pajak final 1\% setiap bulan. Nama informan disamarkan menjadi Tuan D. Pada saat wawancara, istri Tuan $\mathrm{D}$ berada di tempat sama. Nyonya $\mathrm{N}$ juga memberikan pendapat dan menceritakan pengalamannya pada saat wawancara sehingga dapat dikatakan ada dua orang informan pada penelitian ini. Sebagai gambaran informan, Tuan D berusia 73 tahun sedangkan Nyonya $\mathrm{N}$ berusia 66 tahun.

Peneliti menggunakan fenomenologi transendental karena ingin memahami apa yang dialami oleh informan atau disebut "aku" sehingga "aku" melakukan pemaknaan atas suatu hal tertentu (Kamayanti, 2016: 151). Alur analisis data yang ditempuh peneliti adalah noema, noesis, intentional analysis, eidetic reduction (Kamayanti, 2016: 157). Noema merupakan kesadaran yang tampak dari informan, yang harus digali peneliti untuk menghasilkan noesis. Intentional analysis adalah analisa yang dilakukan peneliti untuk menelusuri noesis yang membuat informan mengalami noema, atau dengan kata lain mencari niatan informan dalam melakukan sesuatu. Terakhir, proses eidetic reduction merinci kesadaran infroman yang ditangkap peneliti menjadi lebih detil.

Teknik pengumpulan data yang dilakukan peneliti terdiri dari beberapa langkah, yaitu pendekatan secara personal untuk mengetahui keadaan informan dilakukan dengan cara observasi. Hal ini dilakukan untuk mengetahui kebiasaan, kondisi informan beserta usaha yang dilakukan, serta memudahkan peneliti memahami inti percakapan yang peneliti lakukan. Langkah selanjutnya adalah melakukan wawancara tak terstruktur dan mendalam. Peneliti tidak menggunakan pedoman khusus dalam wawancara karena tujuan mengupas kesadaran terdalam informan. Informan dipersilahkan untuk mengungkapkan apa yang dirasakan mengenai e-billing untuk kemudian dilakukan bracketing dalam pernyataan tersebut. 


\section{HASIL PENELITIAN DAN PEMBAHASAN \\ Mudahmu Bukan Mudahku}

DJP mengklaim dengan sistem pembayaran dan pelaporan terelektronisasi dapat mempermudah wajib pajak untuk melaksanakan kewajiban perpajakannya kapanpun dan dimanapun mereka berada. Ternyata wajib pajak tertentu, sistem terelektronisasi justru dianggap menyusahkan. Wajib pajak ini adalah wajib pajak sudah berusia lanjut dan tidak mengikuti perkembangan teknologi, seperti Tuan D. Setali tiga uang, Nyonya N, meskipun bukan wajib pajak, namun memiliki karakteristik sama. Nyonya $\mathrm{N}$ tidak merasa e-billing itu sulit (noema) karena ketidakpahaman atas teknologi ditunjukkan oleh pernyataan:

\section{“Aplikasi itu apa?"}

Menurut Nyonya N, kriteria mudah adalah sesuatu yang ia mengerti, tidak pandang untuk jenis aplikasi apapun. Nyonya $\mathrm{N}$ menyamaratakan segala yang terelektronisasi merupakan hal susah (noesis).

"Soalnya ga ngerti. Lhawong dikasitau apa aja itu sama Bank ABC (tempatnya menabung) via sms ga ngerti kok."

Selain itu Nyonya N juga menganggap wajar ketidakbisaannya akan teknologi terkini dengan membandingkan dirinya dengan orang lain (noesis).

\section{"Bapak opo iso?"}

Nyonya $\mathrm{N}$ menolak penggunaan e-billing sebagai kesadaran yang tampak karena menganggap semua yang berbau elektronisasi adalah hal susah. Nyonya $\mathrm{N}$ bahkan tidak merasa terbebani oleh ketidakmampuannya karena orang terdekatnya juga tidak menguasai e-billing. Pemahaman "aku" oleh Nyonya $\mathrm{N}$ menunjukkan bahwa e-billing wajar tidak digunakan untuk orang tidak paham teknologi.

\section{Terusiknya Kepercayaan Wajib Pajak}

Tuan D beranggapan kemudahan dalam melaksanakan kewajiban perpajakan merupakan suatu kegiatan yang tidak melibatkan proses dan berbagai macam kegiatan. Pemakaian e-billing memerlukan berbagai langkah pada tahap sosialisasi awal, termasuk menyiapkan NPWP, sarana untuk membuat email, sms, atau ke kantor pajak langsung. Pembayaran pajak terdahulu, yang masih menempuh cara manual, mengharuskan wajib pajak mengisi formulir SSP yang dapat diambil sebelumnya dari KPP. Pembayaran dengan cara ini sudah dianggap pelaporan pajak sekaligus. Kerinduan akan sistem terdahulu diungkapkan Tuan D, kok sulit?!"

"Banyak yang protes, minta kembali ke yang dulu. *nada meninggi* Mau bayar pajak aja

Wajib pajak dapat menyimpan banyak SSP untuk diisi di rumah dan langsung menuju kantor pos atau bank untuk membayarkan pajaknya. Perbedaannya antara jalur pembayaran manual dan terelektronisasi jelas terletak pada jalur yang ditempuh. Tuan D mengungkapkan bahwa,

\section{"Pengennya ya langsung bayar. Bayar ya bayar. Selesai urusannya."}



bisa."

"Pokoknya ya gitu itu. (Di)buatin e-billing nya, kalo cuma bayar ya ke kantor pos, saya

Pernyataan itu menunjukkan bahwa Tuan D bahkan menghendaki sistem yang paling sederhana, yaitu bayar tanpa ada pencatatan. Saat peneliti menelusuri lebih lanjut, Tuan D mengungkapkan salah satu perasaan tidak mudahnya muncul karena anggapan pelaporan pajak dilakukan berulang-ulang, yang ternyata berasal dari pelaporan bulanan dan tahunan yang dianggap sama. Tuan $\mathrm{D}$ belum memahami bahwa pelaporan pajak tahunan bermanfaat untuk mengonfirmasi segala aktivitas yang bersifat ekonomi dan administrasi pajak yang sudah dilakukan selama setahun untuk mengetahui lebih atau kurang bayar. Menurut Tuan D, pajak itu hanya urusan membayar.

\section{"Lha susah e sekarang. Disuruh bolak-balik laporan."}

Saat Tuan D mengurus pajak untuk diri sendiri, ia merasa kesulitan dengan cara yang menurutnya berbelit untuk pajak berdasarkan PP no 46 tahun 2013. Kejadian ini terjadi pada saat Tuan D mengurus SPT Tahunan pertama kali.

"Pokoknya dikasitau harus ke loket yang mana, ke ruang berapa. Trus ditanyain, Bapak/Ibu ini sebenernya keberatan nggak kalo bayar pajak? Ga papa kok sebenarnya kalo mau bayar asalkan ga dikorupsi. Yang golongan 3A yang itu (Gayus) punya milyatan (milyaran). Pas itu juga ditunjukkan harus ke sini dulu baru kemana. Kok angel (sulit) gitu sih, dari sini harus ke sana." (Tuan D)

Ternyata Tuan D merasakan berbelit tidak hanya untuk proses pelaporan SPT Tahunan, tapi juga pada saat ada perbaikan SPT. Tuan D menceritakan proses revisi SPT yang sampai tiga kali padahal merasa sudah melakukan berdasarkan yang diminta oleh fiskus. Tuan D mendapat panggilan lagi ke KPP setelah perbaikan kedua kalinya, namun tidak dilaksanakan karena merasa sudah menyerahkan dokumen dengan lengkap. Tuan D merasa jengkel dengan panggilan perbaikan pelaporan pajak yang berulang kali dilaksanakan, namun masih belum dianggap benar (noesis).

Selain itu, ada rasa jengkel atas kasus yang pernah menimpa DJP beberapa tahun lalu sehingga merasa tidak yakin atas kepatuhan yang Tuan D lakukan (noesis). Tuan D bahkan mengalami hal serupa pada saat mengawasi perdagangan di sebuah pasar di Kota Madiun sekitar 30 tahun yang lalu. Kesadaran terdalam informan menunjukkan pengalamannya yang mengecewakan saat berurusan dengan oknum yang mengaku petugas pajak. Kejadian 30 tahun lalu tersebut berlokasi di salah satu pasar di Madiun. Petugas yang mengaku dari dinas pajak itu memungut pajak dari barang dagangan tertentu. Saat pedagang merasa keberatan dengan tagihan tersebut, si oknum menawarkan pembayaran yang lebih sedikit nominalnya kepada dirinya. Kekecewaan ini membekas di ingatan Tuan D sehingga ia merasa tidak percaya dengan pemerintah hingga saat ini, termasuk untuk pengelolaan dana pajak. Pertanyaan Tuan D menyiratkan keinginan untuk patuh dengan segala tata cara asalkan pemerintah menjamin penggunaan dana pajak sesuai dengan yang semestinya, dari rakyat dan untuk rakyat.

Tuan D enggan menggunakan e-billing karena dipicu oleh tata cara perpajakan yang rumit, sehingga membuahkan kesadaran terdalam dengan membandingkan kesulitan yang dialami pada saat pembayaran manual akan berlipat ganda saat Tuan D mengaplikasikan e-billing. Rasa segan itu juga dipicu oleh imej buruk Perpajakan 
Indonesia beberapa saat lalu. Pemahaman "aku" oleh Tuan D menunjukkan bahwa "aku" wajar tidak menggunakan e-billing karena sudah merasa kesulitan pada saat menggunakan tata cara manual dan "aku" sangsi bahwa pemerintah bebas korupsi.

\section{SIMPULAN}

Keengganan menggunakan e-billing menurut Nyonya $\mathrm{N}$ adalah suatu hal yang wajar jika wajib pajak tidak menguasai teknologi. Sedangkan Tuan D mempertimbangkan kerumitan tata cara pelaporan pajak manual rekam jejak skandal di pemerintahan dan pengalaman masa lalunya menghadapi oknum pajak untuk memutuskan menggunakan sistem pajak yang terelektronisasi, dalam kasus ini adalah e-billing. Pemerintah perlu memperhatikan wajib pajak yang merasa tidak mampu dengan sistem terelektronisasi dengan masih mengadakan sistem pembayaran dan pelaporan pajak manual. Pemerintah, khususnya DJP, perlu menegaskan perannya sebagai badan yang khusus menangani administrasi pajak, sehingga bebas korupsi. Kolusi juga harus dijamin tidak akan terjadi karena pajak dikenakan pada semua warga negara dengan tidak memandang status apapun.

Peneliti memperoleh keterangan dari dua informan sekaligus dengan sekali bertanya. Hal ini menyulitkan peneliti melakukan bracketing, karena respon antara kedua informan dapat saling mempengaruhi dengan saling sahut pada saat wawancara. Saran untuk penelitian selanjutnya adalah benar-benar memilih lokasi wawancara yang membuat informan fokus. Kehadiran pihak ketiga antara peneliti dan informan utama dapat mempersulit analisis data.

\section{DAFTAR PUSTAKA}

Ajzen, I. (1991). The theory of planned behavior. Organizational Behavior and Human Decision Processes, 50, 179-211.

Angkasa, M. (2017, April 15). Bayar Pajak Kok Susah. Jawa Pos, p. 4.

Budiarto, E. (2017, April 28). Bikin Kode Billing Lebih Awal. Jawa Pos, p. 4.

Chua, W. F. (1986). Radical Developments in Accounting Thought. The Accounting Review, LXI(4), 601-632.

James, S., dan Alley, C. (2002). Tax compliance, self-assessment and tax administration. Journal in Finance and Management in Public Services, 2(2), 27-42.

Kamayanti, A. (2016). Metodologi Penelitian Kualitatif Akuntansi: Pengantar Religiositas Keilmuan. Jakarta: Yayasan Rumah Peneleh.

Saad, N. (2014). Tax Knowledge , Tax Complexity and Tax Compliance: Taxpayers ' View. Procedia - Social and Behavioral Sciences, 109(1), 1069-1075.

Sapiei, N. S., dan Kasipillai, J. (2013). Impacts of the Self-Assessment System for Corporate Taxpayers. American Journal of Economics, 3(2), 75-81.

Yusdita, E. E. (2016). Tinjauan Kepatuhan Wajib Pajak Berdasarkan Teori Perilaku Terencana dan Teori Psikologi Fiskal. Universitas Brawijaya. 
